\section{1. 反应機橧}

翼相禾の区公では抬散，吸着，化学反店などが相継い で起り，その機構も反応の種類によって区々のめので, 一律に取扱うことは難しく、いずれの場合も実臨的に得 られるのは䌁括の反仝速度である。しかしこの反応機模 を知ることは圧力, 温度, 組成, 空間速度および反応率 などに関保した操作上の最邀条件を定るる上でる有力な 手掛りとなる境合が多い。

一般の接保反结では抬散，螌媒粒子内抬散の物理的段 階々触媒界面上の反応物の吸着, 活性座 (active sites) における化学反忘, 生成物の晟脱などの化学的段階々が 組合さって起るるので, 総括的な造度は近似的に次式で

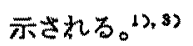

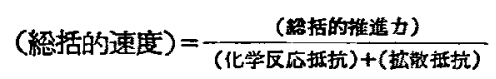

$$
こ こ て
$$

(総括的推進力) $=$ (化学反応推進力) + (抬散推進力) (HRU) の殹念》 す根本的にはこの式の単なる变形に

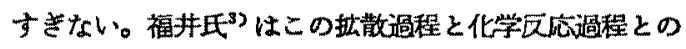
相互関係について理論的な㺟析を行っている。

さらに砤視的に固体表面における気相接能反応の機構 を考えると，次の段階か存在する。(2,5)

1) 物理的段階

a. 気相本体上り能媒素面人の反店物の执散

b. 触媒內の反应物，生成物の拉散

c. 生成物の気相本体人の抬散移動

2) 化学的段啮

a. 触媒活性座上の反応物の活性吸着

b. 活性座下起る分子会合, 解端

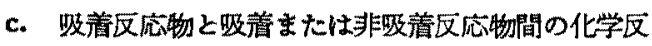
応

d. 生成物の触媒からの活性襍脱 (activated desorption)

たとえば $\mathrm{A}+\mathrm{B} \leftrightarrows \mathrm{R}$ なる気相接触反底を考劣る

第
大 竹 傅 雄**

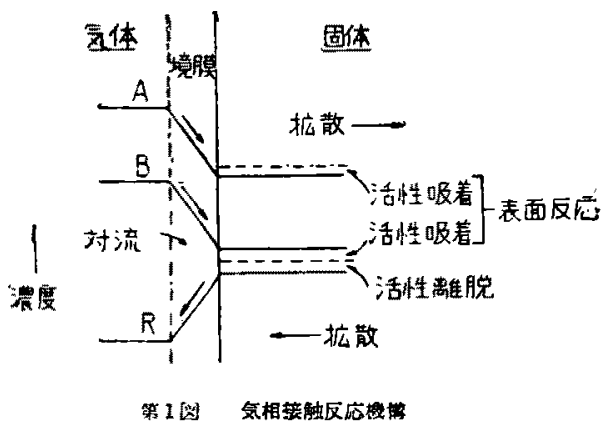

1 图)。民応物 A，B は気相本体上り触媒外或血门移動

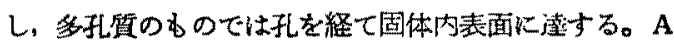
B間て反応か起り，おらかてめAまたはBで占められ た活性座の一つに活性吸着された生成物Rを生ず。つい

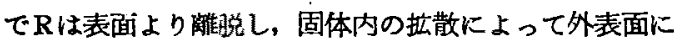
もどり，対流搪散に上り外表面から気相本体へもどって 行く。すなわり触媒走面人の正逆の物質移動および粒子 内の移動は対法，拉散の物理的段階であり，活性吸着， および表面反応は化学的なるのである。

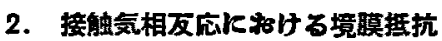

気相接触反応ではガス境膜が総括反店速度に抵抗を示

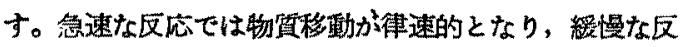

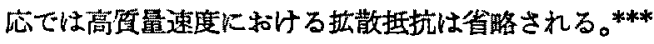

触媒表面における反応速度を実験的に究明するには, 表面反応担抗に比して，境膜抵抗を省略できるような高

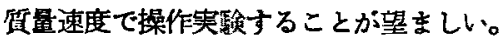
充埴層の物啠移動速度の一般式は次式で示され，**** 定常状態では，これは反店速度 $r$ に等しく，

$$
r=r_{d}=k_{G} a_{m} \Delta p_{A} \text { たたし } A p_{A}=p_{A}-p_{A i}
$$

$p_{A}, p_{A t}$ : 気相本体, 粒子表面のAの分压, $a_{m}$ :触媒 単位質量当 $\boldsymbol{D}$ の表面䖽， $k_{G}$ : 物質移動保数。

$\boldsymbol{k}_{g}$, あるいは反应系の搪散的物性 $S c h$ 数をる考慮に 入れた $j_{a}$ 因子は $R e$ 数の函数であり，

$$
j_{a}=a\left(\frac{\sqrt{a_{p} G}}{\mu}\right)^{-n}=\left(\frac{k_{G} M_{m} p_{I}}{G}\right)\left(\frac{\mu}{\rho D_{A}}\right)^{2 / 3}
$$


ここに, $a_{p}$ : 粒子の外表面程, $G$ : 反応流体の益量速

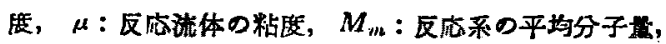
$P$ : 反店流体の密度， $D_{A}$ : ガス混合系中のAの应散保数,

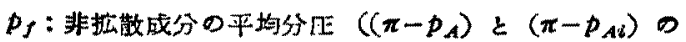
対数平均值)， $a, n$ : 贸検常数

（2）と（3）试を組合初せて，

$\Delta p_{A}=\frac{1}{a}\left(\frac{V a_{p} r M_{m} p_{f}}{p_{A} \mu a_{m}}\right)\left(\frac{\mu}{\rho D_{A}}\right)^{2 / 3}\left(\frac{\sqrt{a_{p}} G}{\mu}\right)^{n-1}$

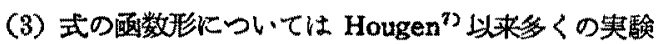
的関係式か゚提出されて和り，さらに固定尿，流動留の結

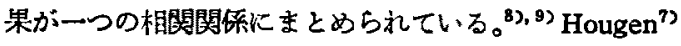
らの絬果によっを， $\sqrt{a_{p}} G / \mu<620 に て a=2.44$, $n=0.51, \sqrt{a_{p}} G / \mu>620$ にて $a=1.25, n=0.41 \tau$,

$$
\left(\frac{V a_{p} r M_{m u} p_{1}}{p_{A} \mu a_{m}}\right)\left(\frac{\mu}{\rho D_{A}}\right)^{2 / 3}=X
$$

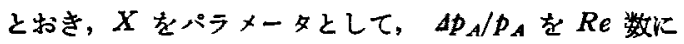

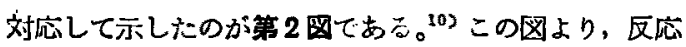
系の物性定数および反応速度から触媒表面に特ける成分 $A$ の分圧が算出される。物澌移動に上る抵抗は $\Delta p_{A} / p_{A}$ が小さいはど小さい。すなわち X が小さく，Re 数大

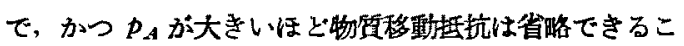
とになる。

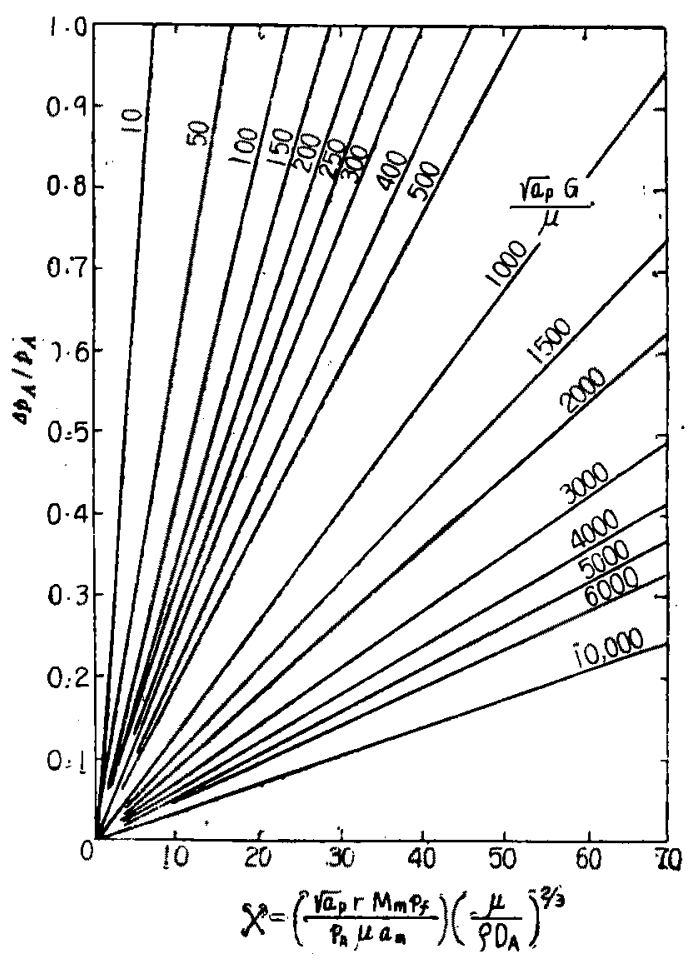

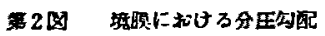

同様にして触媒粒子と反応ガスとの伝熱速度 qにつ いてる次の関保式が尊かれる。

$$
\begin{aligned}
q=h_{G} a_{n t} \Delta t=-\Delta H_{r} \\
\frac{\Delta t}{t}=\frac{1}{a^{\prime}}\left(\frac{r \Delta H \sqrt{a_{p}}}{a_{m} \mu C_{p} t}\right)\left(\frac{C_{p \mu}}{\lambda}\right)^{2 / 3} \\
=\left(\frac{\sqrt{a_{p}} G}{\mu}\right)^{n-1}
\end{aligned}
$$

ここに $\Delta H:$ 反掂熟, $\Delta t=\left(t-t_{t}\right)$ 氮相と固体装面

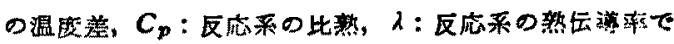
むる。

$$
\left(\frac{r \Delta H \vee a_{p}}{a_{m} \mu C_{p} t}\right)\left(\frac{C_{p} \mu}{\lambda}\right)^{2 / 3}=X^{\prime}
$$

とおいて， $X^{\prime}$ をバラメータとして $\Delta t / t$ を $R e$ 数の函 数として図示されており, ${ }^{102}$ 反応速度 知られると， $\Delta t$ すなっち触媒表面温度が求められる。

むし $\Delta p_{A} / p_{A}$ かi 1 にな九机物筫移動が完全に支配的と なる。この極限の条件は理想的触媒による反度速庭のの 場合で，このときは総括反応速度は反応物，生成物の应 散速度に完全に支配される。

$X ， X^{\prime}$ には反底速㡲 $r$ を含むのて，一般の反底で $p_{A d}$

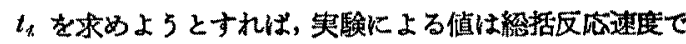
あるから，したがって試算によらねばならない。界面反 応 1 次の場合には，HRU 法によって扩散拱抗と反分抵 抗とを分散することができる。2》,112,12)

なお粒子表面が全て反応にあずかるとの前提のるとに

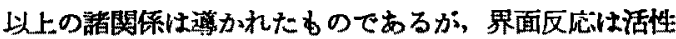
座でおこるあのであり，厸散にあずかる界面と反応にあ ずかる界面とが必ずしる一致するとは限らない。これに 開する研究はすくないが，淮藤氏 ${ }^{132,332}$ らは触媒粒子の

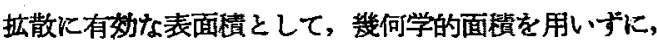

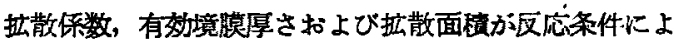
ってそれぞれ变動する定数としてこれらを一括した触 媒容赦当りの物貿移動保数を探用した。

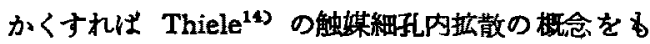
ある程度近似的に包含することができ，位来の方法が物 質移動保数として化学反应を伴わない実駼条件からえら れた值をそのまま類推して使用するのに対し，本法では 化学反坑の将から求められるるのであり，一段と進ん ではいるが，执散措抗の分離には 2 重の試算を必要とす

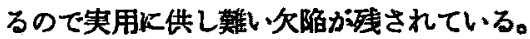

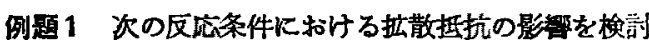
せよ。触媒 $d: 3.2 \times 3.2 \mathrm{~mm}$ 円密，見詓け密唐 $\rho_{B}$

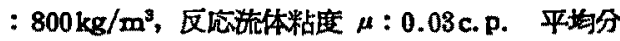
子量 $M_{m}: 50$, 触媒空腺深 $F_{e}: 0.40, S_{6} h$ 数 $\left(\mu / P D_{A}\right): 1.50$

解 $d=0.0032 \mathrm{~m}, d_{p}=\sqrt{1.5} d=0.0089 \mathrm{~m}$, 


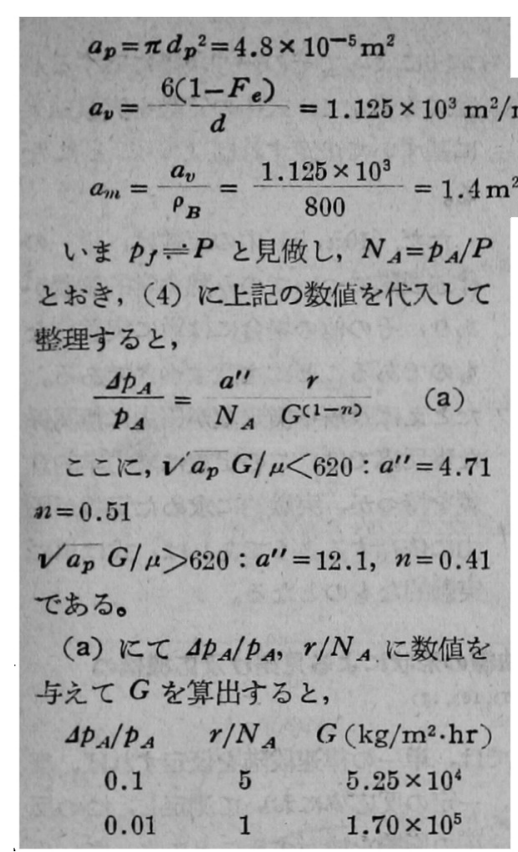

したがってもし10\%の諤库が許され るなら仕，留㩆速度 $5.25 \times 10^{\circ}$ のと

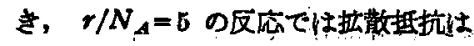
省略される。重た $r / N_{A} か ゙$ なる反

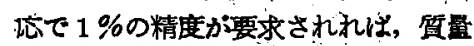
速度 $1.70 \times 10^{\circ}$ 以上で実験を行うへ きことになる。

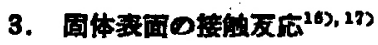

接触反応汒反応物質の活性吸着, 表 、面反底たよび生成物の離脱などが絸合 さって起るわのであるが，これら過程 のうち最す遇いるのが律速段階となり 見脚けの反应速度はこれによって決定 される。文, (5), 153

Hougen, Watson ${ }^{6}$ 《定常流通䒺 の気相接触反応について,この吸着, および化学反応を律速段階とする㮔ね の反应機棈について速度式を提出した が, さらK Yang, Hougen ${ }^{103}$ は, こ れらの式を綾括して次式でまとめた。

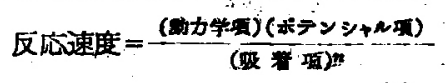

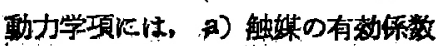

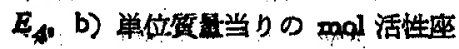

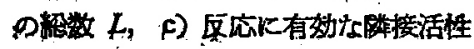
度の数 $s ， \oint$ 律速段階の速度定数

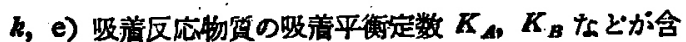
まれる。

ポテンシャル項には，a）反広物筫，生成物の界面に おける活量 $a, b)$ 固体表面濃度に対する気相中の総括

\begin{tabular}{|c|c|c|c|c|}
\hline \multicolumn{5}{|c|}{ 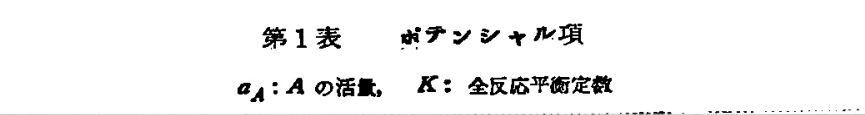 } \\
\hline 分 & $A \leftrightarrows R$ & $A \hookrightarrow R+S$ & $A+B \leftrightarrows R$ & $A+B \leftrightarrows R+S$ \\
\hline$A の$ 吸首過程律速 & $a_{A}-a_{R} / K$ & $a_{A}-a_{R} a_{S} / K$ & $a_{A}-a_{R} / K a_{B}$ & $a_{A}-a_{R} a S / K a_{B}$ \\
\hline Bの吸箸過程律速 & 0 & 0 & $a_{B}-a_{R} / K a_{A}$ & $a_{B}-a_{R} a_{S} / K a_{A}$ \\
\hline Rの離脱過程律速 & $a_{A}-a_{R} / K$ & $a_{\Lambda} / a_{S}-a R / K$ & $a_{A} a_{B}-a_{R} / K$ & $a_{A} a_{B} / a_{S}-a_{R} / K$ \\
\hline 表面反応律速 & $a_{A}-a_{R} / K$ & $a_{A}-a_{R} a_{S} / K$ & $a_{A} a_{B}-a_{R} / K$ & $a_{A} a_{B}-a_{R} a_{S} / K$ \\
\hline 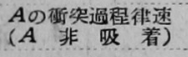 & 0 & 0 & $a_{A} a_{B}-a_{R} / K$ & $a_{A} a_{B}-a_{R} a S / K$ \\
\hline 均一反応 & $a_{A}-a_{R} / K$ & $a_{A}-a_{R} a_{S} / K$ & $a_{A} a_{B}-a_{R} / K$ & $a_{A} a_{B}-a_{R} a_{S} / K$ \\
\hline
\end{tabular}

第2表動力学 項

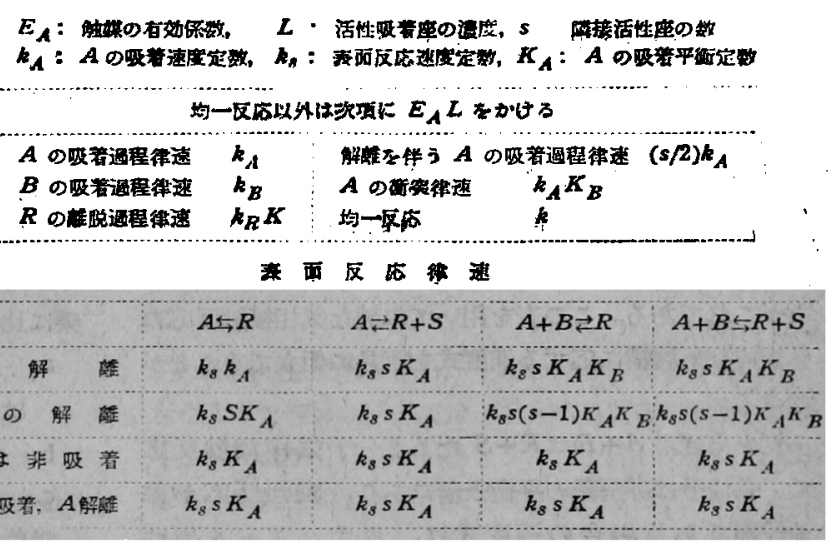

\section{第3表睡曾 项}

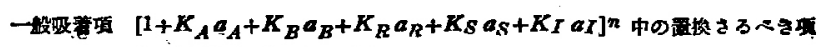

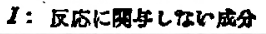

\begin{tabular}{|c|c|c|c|}
\hline 反 & $A \leftrightarrows R$ & $A+B \rightleftarrows R$ & $A+B \rightarrow R+S$ \\
\hline 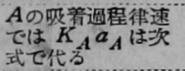 & $K_{A} a_{R} / K$ & $K_{A} a_{R} / K a_{B}$ & $K_{A} a_{R} a_{S} / K a_{B}$ \\
\hline $\begin{array}{l}B \text { の旳普過程律速 } \\
\text { では }{ }_{B}^{a} B \text { は }\end{array}$ & 0 & $K_{B} a_{R} / K a_{A}$ & $K_{B} a_{R} a_{S} / K a_{A}$ \\
\hline $\begin{array}{l}R \text { の矢脱過程律速 } \\
\text { では } K R a_{R} \text { は }\end{array}$ & $K K_{R} a_{A}$ & $K K_{R}\left(a_{A} / a_{S}\right) \quad K K_{R} a_{A} a_{B}$ & ${ }_{\left(a_{A} a_{B} / a_{S}\right)}$ \\
\hline 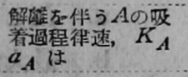 & $\sqrt{ } K_{A} a_{R} / K^{-}$ & $\sqrt{K_{A}^{a_{R} a_{S} / K}} \quad \sqrt{K_{A} a_{R} / K a_{B}}$ & $\sqrt{K_{A} a_{R} a_{S} / K a_{B}}$ \\
\hline 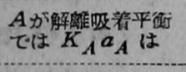 & $\sqrt{K_{A} a_{A}}$ & 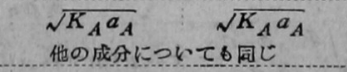 & $\sqrt{K_{A} a_{A}}$ \\
\hline $\begin{array}{l}A か ゙ \text { 吸䖭されない } \\
\text { とさ } K_{A} a_{A} \text { は }\end{array}$ & 0 & 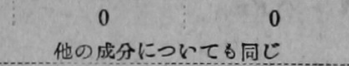 & 0 \\
\hline
\end{tabular}


第 4 表 暖着項の指数 $n$

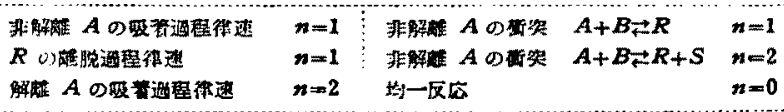

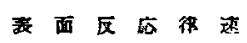

\begin{tabular}{|c|c|c|c|c|}
\hline & $A \rightleftarrows B$ & $A \leftrightarrow R+S$ & 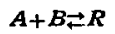 & $A+B \leftrightarrows R+S$ \\
\hline 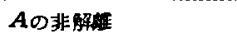 & 1 & 2 & 2 & 2 \\
\hline Aonarite & 2 & 2 & 3 & 3 \\
\hline Aの解烧 (B韭眼者) & 2 & 2 & 2 & 2 \\
\hline 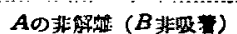 & 1 & 2 & 1 & 2 \\
\hline
\end{tabular}

车法によってその律速段陼に応する速 度式を組立て, 式中の定数を央験結果 に基すいて決定すればよいことにな る。

たた $(10 \mathrm{a}, \mathrm{b})$ 中の定数は, 単一の 律速段階についての及熱力学的恋義が あり，その他の場合には単に実験的な るのであることに注意すべきである。 たとえに゙吸着平衡定数が注力作無関係 な素反店では，この定数は熱力学的意

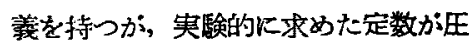
カに位存するようであれば, 式は単に 实験的なものとなる。
平衡定数 $K$ が合まれ, 化学平衡の条件では,ポテンシ ヤ項は 0 となる。

吸着項には，a）反応物，生成物および不活性成分に よる活性座の埃䪔，b) 指数 $n$ すなから表面反応関与 ナる疄接活性座の数がふくまれる。

この他触媒の活損 (deactivation) は触媒項に他の項 を附加することにより，ま大㭙間の函数としての触媒能

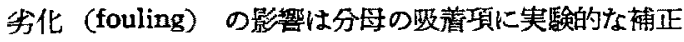
項をつけ加えることによって表現される。

Yang, Hougen は単純な可逆気相接触応について, 各項の形式および指数 $n$ の值を表示している。第 $1 〜 4$ 表がこれである。この表を用いて単綀な気相接触反応の

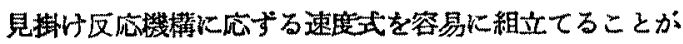
できる。

たとえば， $A+B \leftrightarrows R+S$ なる 2 分子荠相接触反応 で，各成分は非晖隻の平衡吸着にあり，表面反応が律 速段階である場合の速度式は，ポテンシャル項は $\left(a_{A} a_{B}-a_{R} a_{B} / K\right)$, 動力学項は $k_{B} s K_{A} K_{B} E_{A} L$, 吸湆 項は $\left(1+K_{A} a_{A}+K_{B} a_{B}+K_{R} a_{R}+K_{S} a_{B}\right)^{2}$ であり，し たがって,

$$
r=\frac{E_{A} L s k_{B} K_{A} K_{B}\left(a_{A} a_{B}-\frac{a_{R} \dot{a}_{S}}{K}\right)}{\left(1+K_{A} a_{A}+K_{B} a_{B}+K_{R} a_{R}+K_{B} a_{B}\right)^{2}}(10 \mathrm{a})
$$

むた同一反闷で，A の昅着過程が律速で，A が吸 着に祭し解離する場合の速度式は，ボテンシャル項は $\left(a_{A}-a_{R} a_{\mathcal{B}} / K a_{B}\right)$, 動力学項は $E_{A} L s k_{A}$, 吸着項の $K_{A} a_{A}$ は $\sqrt{K_{A} a_{R} a_{S} / K a_{B}}$ て置換されて，

$$
r=\frac{\left(E_{A} L s k_{A}\right)\left(a_{A}-\frac{a_{R} a_{S}}{K a_{B}}\right)}{\left[1+\sqrt{\frac{K_{A} a_{R} a_{S}}{K a_{B}}}+K_{B} a_{B}+K_{R} a_{R}+K_{S} a_{S}\right]^{2}}
$$

かくして実験的に接触反応の律嗃段階を明かにして，

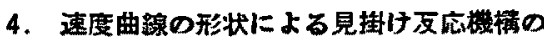 推定 ${ }^{10), 103,17)}$}

気相接強反心では，単一の律速段階を仮定すれは2，反 心速度を定温で，一定の反応率においてて測定し，この反 応速唐に対寸る全王の影帮を柃討することによってそ！

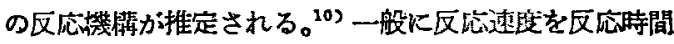
0に補外しだ初期反空速度にとると，データの相閶は容 易であり，多くはこの初期反结速度が比較される。

2 分子気相接触反応で，表面反応律速の場合の初期反 応速度に対する圧力の影帤を第 3図に示した。かかる化 学反応律速的な場合には，低圧ではすべて速度は圧の2 乗に比例して増加し，ついて各譏構に往って，

a. 王ととす火制限なく增大する場合：10反度物望 は非吸着

b. 最大值に漸次近接：2 成分とも非解離吸着

c. 極大值を有する場合：1成分が解離吸着

吸着過程律速の2 分子反心については第 4 因に示し たo

a. 圧と直線的に堌大：1 成分のみ吸菬

b. 直線的よりすくなめに増大：B の喥着律速， $A$ は 解滩

c. 最大值に嗨近：B は平衡吸着, $A$ の吸着律速

d. 極大值存在: $B$ は解陮吸着， $A$ の昨着律速

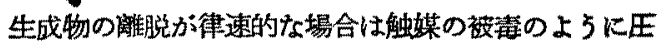
に無関係。

単分子反応に対する圧の影翋は第5四。

a. 压とともに直線的に堌大：呂着過程律速

b. 最大值人謴近 : 単一活性座の表面反成速

c. 極大値存在 : 表面反応律速, 2 元活性坐で起る

かくして見掛けの律速段階が恝験的に沠かられるが， これにはかなりの努力が要求される。かくして見掛け极 杵が决定されれば，相当する式中の定数は定温の実験結 

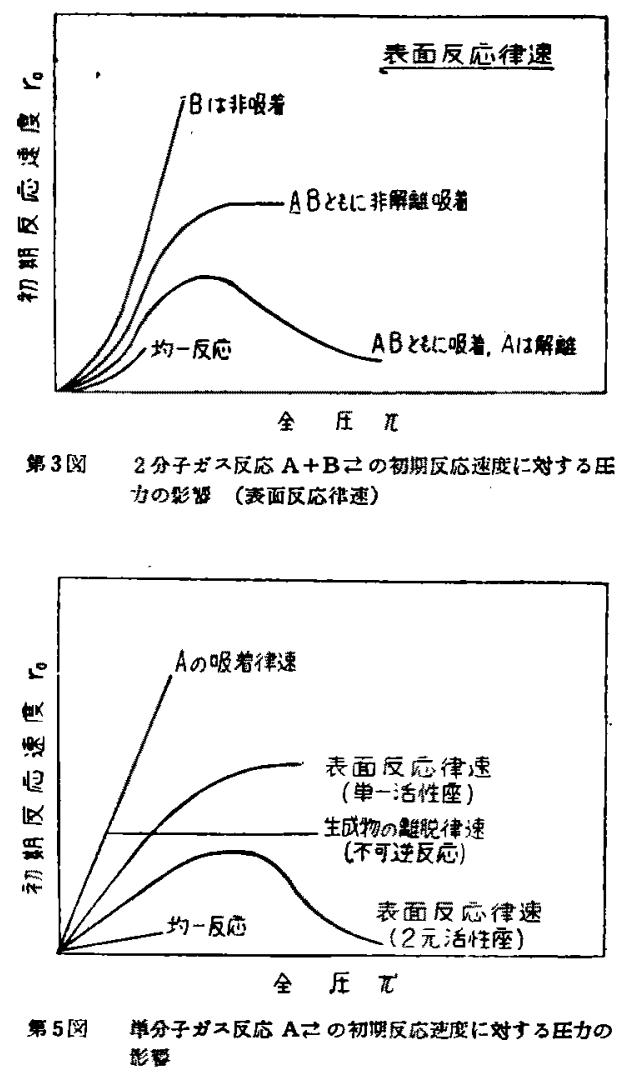

果かっら最小2乗法によつて洪定される。*

\section{5. 反应速度に対す万温度の影行 ${ }^{16), 17)}$}

反応速度に対する温度の影暗は律速段階の見掛けの活 性化エネルギーおよび吸着成分の活性吸着エンタルピー を求める上で欠くでからざるのである。

第6图に示す上万に吸着が律速段階の場合には Arrhenius の式にしたがって，不可逆反応では温度の指数㓰 数として增大する。表面反応律速の場合には, 可逆, 不 可逆反応とすに䓧大值か存在する。発熱反応に見られる よ5に反応速度が温度上早につれて減少するような場合 には，一般に平衡状熊人の近接によるるのであるが，不

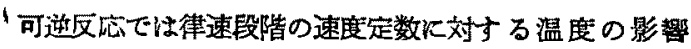
が，触媒表面から反応物の離脱といった好むしくない奻 果を促進することによって相殺される場合にる起る。

かかる温度上昇によって反分速度が減少する場合に は最適反忘温度が存在しこれについては児玉, 福井氏 $5^{183,3)}$ の理論的解析がある。

以上は気相接触反応の素反応に適用される論義である

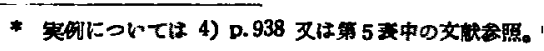

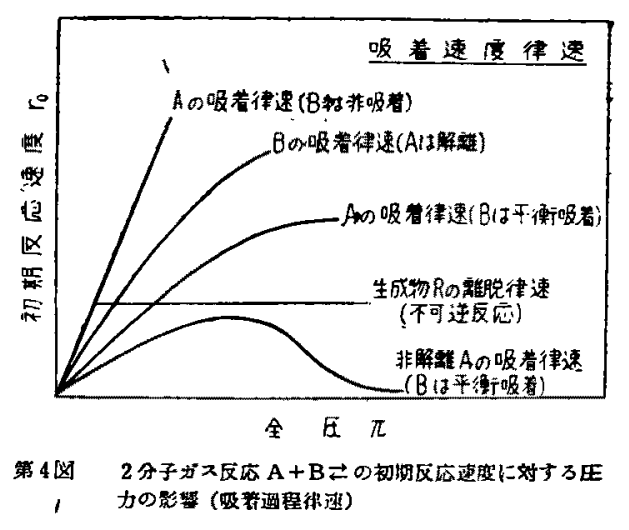

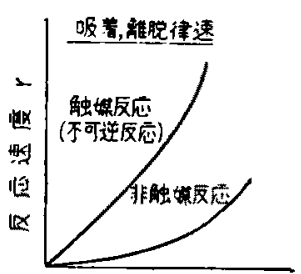

渴度 $t$

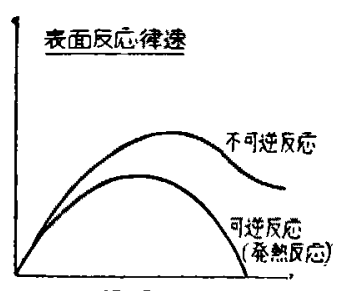

温度 $t$

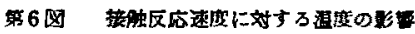

が，数個の生成物を生じ，それが一つ以上の律速段階を るつような被雑な反応では，共存する反応の定数を洪め ることは難かしい。かかるときには上述した解析法に集 して，実験式によって消失速度を表わすようにつとめ る。

\section{6. 触媒の活性度と有効係数}

1) 活性度 (activity) 触媒の活性度を数量的に 表現するには充分調整された実験室の条件で，特定の反 応について反応速度を測定比較して行われる。

流通反応系では特定の反応率に対する速店式は

$$
r=\frac{d x}{d(W / F)}=f(x) L
$$

$L$ : 实験に供した触媒の活性度，W：触媒の面量,

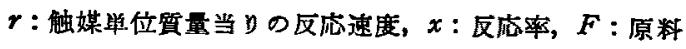
供紿速度

標售の触媒活性度 $L$ っなるるのについても同様に示さ れ，同一の反応活では $f(x) ， d x$ はそれぞれ等しく，し たかって

$$
L_{s} d(W / F)_{s}=L d(W / F)
$$




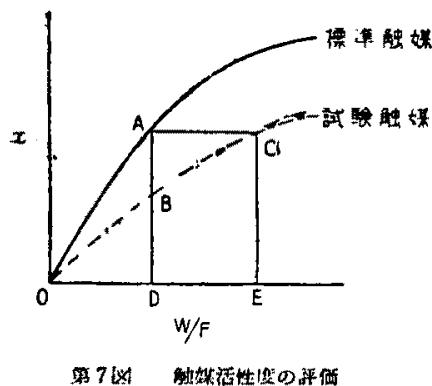

$L_{s}=1$ として锟分すると，

$$
L=\frac{(W / F)}{(W / F)}
$$

（13）式の比率が該当触媒の活性度を示し,

第7图によればこの比は $O D / O E$ で年え られる。

また同一の $W / F$ (流通法)，経過時間(回分法)に和 ける反応率の比較に基つく活性度試験が用いられること るむる。この福合は綈て図の $B D / A D$ の比で与えられ，

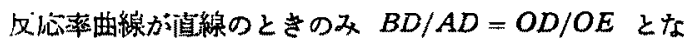

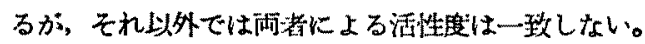

卖際的な試験法には Rescorla, ${ }^{19}$ ) Conn, ${ }^{202}$ Smith $^{212}$ らの研究がある。

2) 有效保数 (efrectiveness factor) $E_{A^{4}}{ }^{13,33}$ 多孔

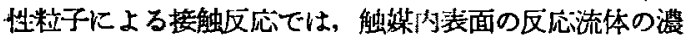
粒子の外表面に括ける值上り小さく，単位界面当り の反応速度は内表面では小さいことはあきらかで，単位 量量の触媒当りの実際の反応速度と，内表面の漕度す外 表面のそれと同一とする反応速度との比を粒子の有効保 数 $E_{A}$ と Thiele14) によって名つけられた。すなわち $E_{A}=1$ とは触媒の内外表面の反应速度か等しいことを意 味し，これには 1)粒子が少さいこと，2）径大きく 内部で速結していること，3）汉沁速度が比較的荤く， 4) 反応物，生成物の搪散倸数が大であればこの条件に 近つくことはあきらかである。Thiele 注触媒が均一泌 度，均一多孔度をもち，吸着，外表面硔を省略するなど の仮定のむとにこれら因子の相互関係を理詥的に尊い た。すなわち

$$
E_{A}=\frac{3}{m^{2}}(m \operatorname{coth} m-1),
$$

$$
\text { ここに }
$$

$$
\begin{aligned}
& m=d_{p^{\prime}} / 2 V k / \overline{c D_{v}} \\
& d_{p^{\prime}}=-\frac{6 V_{p}}{a_{p}}=\frac{6\left(1-F_{g}\right)}{a_{p}}=\frac{6}{a_{m} p_{B}}
\end{aligned}
$$

$m$ : 有效係数 modulus, $V_{y}:$ 粒子平均体狫 $F_{e}:$ 空陪率 $a_{p}:$ 䊉子平均外表面䅠

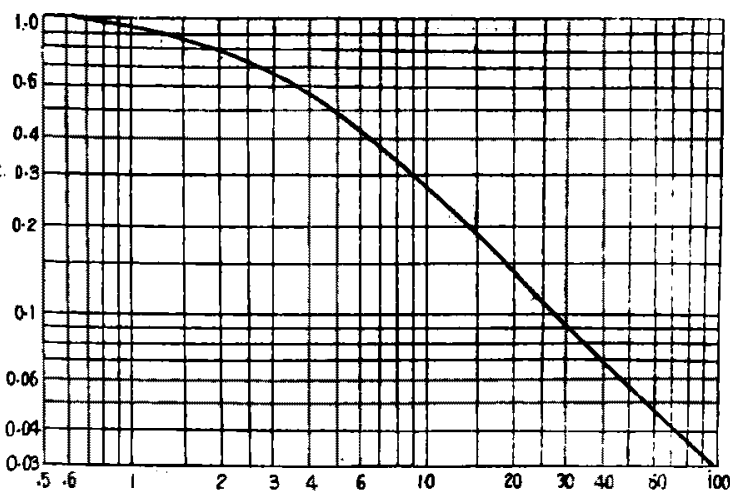

Modulus $m=\frac{d p^{\prime}}{2} \sqrt{\frac{k}{c h}}$

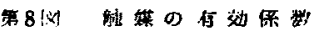

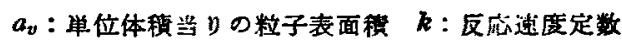

$c:$ 孔の平均半径

$D_{v}:$ 拡散保数

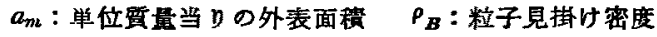
この閣係を図示したのが第 8 図で, modulus $m$ が小さ

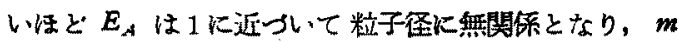
が大きくなると， $E_{A}$ は $m$ に逆比例してくる。この近边 では粒子の外表面のみが汳心あつかることになる。

この理論は実験的な敦付けはなされていないが，興味 あるものである。いま粒于径のみ巽る触媒で実験を行っ た場合，この2つの粒子の有奻俰数の比は反応速度比に 等しく，また $m$ の比は直径の比汇等しい。

$$
\begin{array}{lll}
E_{A_{i}} & =r_{1} \\
E_{A_{2}} & -\frac{m_{2}}{r_{2}}=b, & m_{1} \\
m_{2} & =\frac{d_{1}}{d_{2}}=a
\end{array}
$$

この関係を（14）式に代入して

$$
a m_{2} \operatorname{coth} a m_{2}-1=b a^{2}\left(m_{2} \operatorname{coth} m_{2}-1\right)
$$

（18）式より $m_{2}$ か求市り，（17）式より $m_{1}$ が得占 れ，つで $E_{A_{1}} E_{A_{2}}$ が算出される。

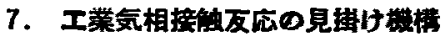

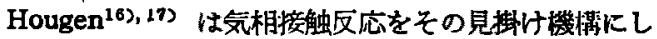
たがって分類している。第 5 表はこれを幾分補足したる のである。な和䮔氏222 は接触反応汇関する交献を主 とめているので,これによって本表の不倩を補っていた だきたい。

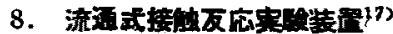

実医装置をその望式によって分類すると（第9図）

I Differential reactors

1. 1 回通過型 once through

2. 循環型 ecirculating

II Integral reactors 


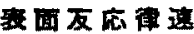

1.

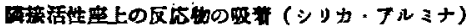

Johanson \& Watson: Natl. Petol.News, Tech. Sec. (Aug., Sep., 1946) 女缺 4) p. 933 部盟

2. Codimer o水 $\mathrm{C}_{8} \mathrm{H}_{16}+\mathrm{H}_{2} \rightarrow \mathrm{C}_{8} \mathrm{H}_{18}$

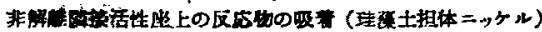
Tschernitz, Bornstein, Beckmann, Hougen : Trans. Am. Inst. Chem. Engrs., 42, 883 (1915)

3. $\mathrm{SO}_{3}$ Otelt $\quad 2 \mathrm{SO}_{2}+\mathrm{O}_{2} \rightarrow 2 \mathrm{SO}_{3}$

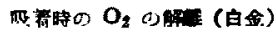

Uyehara \& Watson: Ind. Eng. Chem., 35, 541 (1943)

Olson, Schuler \& Smith : Chem. Eng. Prog., 46 $614(1950)$

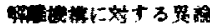

Baron, Manning \& Johnstone: ibid., 48.125(1952)

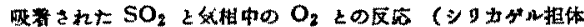
(シタシのん)

Calderiank: Chem. Eng. Prog., 49, 585 (1953)

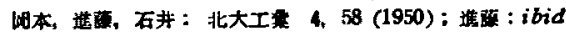
3, 151 (1949)

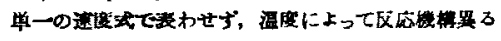

4. n-Butane の院水英

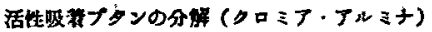

Dodd \& Watson: Trans. Am, Inst. Cherin. Engrs., 42. 263 (1946)

Natt. Petrol. News, 38 No. 27, R 545 (1946)

5. ホタン合成 $\quad \mathrm{CO}+3 \mathrm{H}_{2} \rightleftarrows \mathrm{CH}_{4}+\mathrm{H}_{2} \mathrm{O}, \mathrm{CO}_{2}+4 \mathrm{H}_{2} \rightleftarrows$ $\mathrm{CH}_{1}+2 \mathrm{H}_{2} \mathrm{O}$

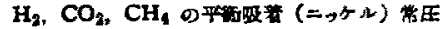

White : Chem Eng. Prok., 44, 533 (1948), 46 563 (1950)

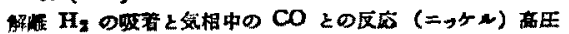
Pursley \& White 他: Chem. Eng. Prog., Srmaposium, 451 (1952)

6. エチレンの水和 $\quad \mathrm{C}_{2} \mathrm{H}_{4}+\mathrm{H}_{2} \rightarrow \mathrm{C}_{2} \mathrm{H}_{6}$

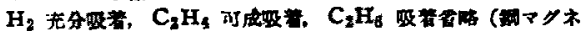
シヤ)

Wilhelm \& Johnson 他：Chem. Eng. Prog., 4105 (1948)

Winkonp \& Wilhelm: ibid., 300 (1950): 流通法

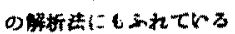

7. $\mathrm{NO}$ oreft $2 \mathrm{NO}=(\mathrm{NO})_{2},(\mathrm{NO})_{2}+\mathrm{O}_{2} \rightarrow 2 \mathrm{NO}_{2}$

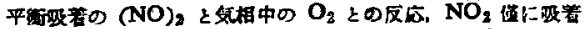

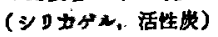

Baker, Wong \& Hougen: Chem. Eng. Prog., Symp. 4103 (1952)

Rao \& Hougen : ibid., 110 (1952)

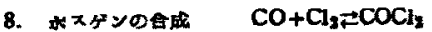

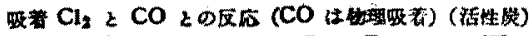
Potter Baron: Chem. Eng. Prok., 47473 (1951)

9. イソプロビルクロライドの合成 $\mathrm{C}_{6} \mathrm{H}_{8}+\mathrm{HCl} \rightarrow \mathrm{C}_{6} \mathrm{H}_{7} \mathrm{Cl}$

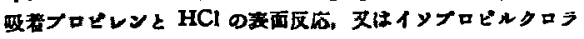
1 Fの模律通

Swabb, Jr \& Hoelscher : Chem. Eng. Prog., 48 564 (1952)
10. Butanol-1 O脱水原店

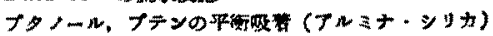

Mauver \& Sliepcevick: Chem! Eng. Prog., Symp. 431 (1952)

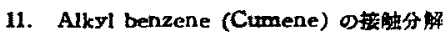

Isopropyl benzene $\rightarrow$ Benzene+Propylene

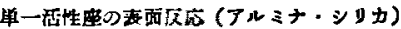

Rase fth: Chem. Eng. Prog., 4003 (1953), 50 35: (1954)

12. n-Butene $の$ 踪水絭 Butene $\rightarrow$ Butadiene

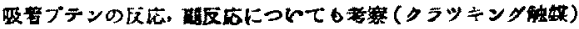
Beckberger \& Watson: Chem. Eng. Prog., 4229 (1948)

13. Schift 反5 $\mathrm{CO}_{2}+\mathrm{H}_{2} \doteqdot \mathrm{CO}+\mathrm{H}_{2} \mathrm{O}$

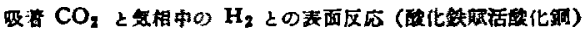
Berkley, Corrigan, Wainright \& Sand : Ind. EngChem., 42066 (1952)

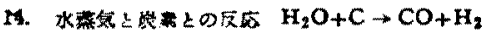

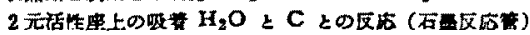

Johnstone, Chen \& Scott: Ind. Eng. Chem., it 1564 (1952)

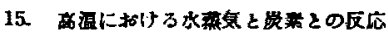
$\mathrm{C}+\mathrm{H}_{2} \mathrm{O} \rightarrow \mathrm{CO}+\mathrm{H}_{2}, \mathrm{C}+2 \mathrm{H}_{2} \mathrm{O} \rightarrow \mathrm{CO}_{2}+2 \mathrm{H}_{3}$

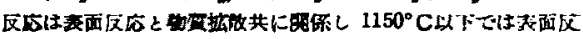

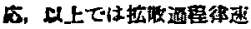

Huat, Mori \& Katz: Ind. Eng. Chemn, 45677 . (1953)

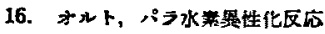

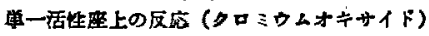

Rogers: Ind. Eng. Chem., 451574 (1953)

17. プロヒレン, エチレンの水添

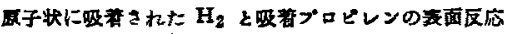

(50-50mol \% 鈰・マグネシャ)

Sussman \& Potter: Ind. Eng. Chem., 46 457(1954)

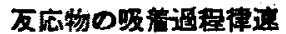

1. アンモニア合战 $\mathrm{N}_{2}+3 \mathrm{H}_{2} \leftrightarrows 2 \mathrm{NH}_{3}$

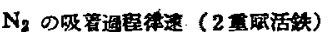

Temkin \& Pyzhev: Acta Physiochim (USSR) 12 327 (1940)

Eramett \& Kummer : Ind: Eng. Chem., 35677 (1943)

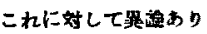

Adams \& Comings : Chem. Eng. Prog., 49359 (1953)

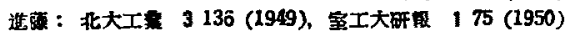

小林 久保田：北大工震 51 (1951)

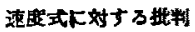

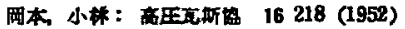

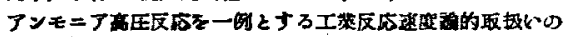

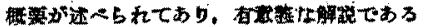

2. エステル化反成

Acetic acid +Ethanol $\rightarrow$ Ethslacetate $+\mathrm{H}_{2} \mathrm{O}$

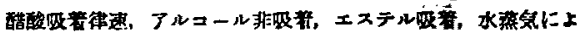
つて促進 (シリカダル)

Buckley \& Altpeter : Chem. Eng. Prog., 47243 (1951) 


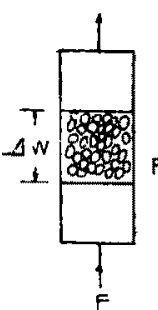

回通遗型

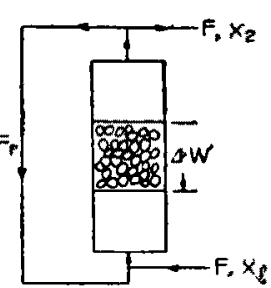

㨁需型

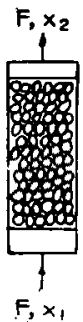

筆一管
策 $9 a$

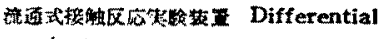
reactors

1. 崖一筞型 Single 2. 直列管型 Series

3. 管壁型 tubular (catalyst in tube walls)

I ) Diferential reactors 之は反応流体の特性变

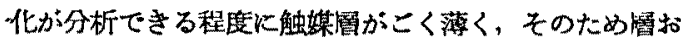
よび流体の平站状態として檿の入口，出口端における温 度，压力および組成の算術平均值が充分な精度で探用で きるような場合をさす。反応流体の組成变化から尊かれ た反応速度は铛分反応速度を表わし，直接これらを既知 の平均条件で表示することができる。

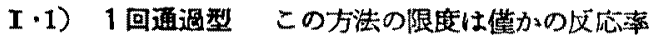
から反応速度を求めるに要求される分析の精度によって 決り，この場会の平均の反応速度は

$$
r=\frac{F \Delta x}{\Delta W}
$$

I -2）潜㻴型 1 回通過型の欠点は反応法体の大半 を偱環することによって除かれる。これによれば新らし い原料嵪い反応害を示すことになる。この方法では少 量の原料で管内の流速を增大することができ，したがっ て拉散抵抗を小さくできる。反応速度は

$$
r=\frac{F\left(x_{2}-x_{1}\right)}{\Delta W}
$$

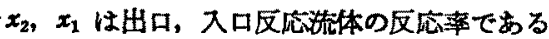

たたこの久点は定常状熊に達するまての時間の長いこ 、とおよび同時に生成物と新らしい原料とが 2 次的な反応 を起しやすいことである。

II）Integral reactors では同咕に起る数個の反 沁の取扱いが可能でかり，これには一般に2つの力策が ある。

II·1）单一壹㤠 一定の容清の触媒を用い・流速を種 々变化させて実験を行5。このときの反応速度は反応率 対 $W / F$ の曲線の傾斜から求められ，これと反応流体 の組成とを相関させて速度式を決定する。このためには 一定条件の原料，同一客棈の触媒に対して流速を变え， あるいは同一流速で強媒量を变支て行5。反応速度は $r=d x / d(W / F)$ で与えられる。反応機構が知られると

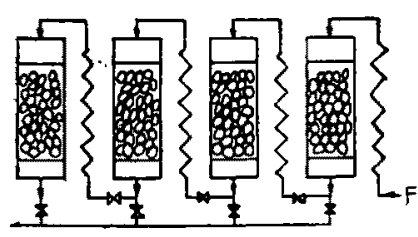

直 列管型

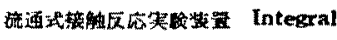
reactors

この式を荅全域につい て棈介することがで き,これによつて速度 式中の各定数を做定士 る。

II.2）面列管型

この埸合は反心器の連 結部でそれぞれ試料を 分析して，一回の実験 Kよって数個の $W / F$ が求高り，各武料より 速度式を決めることができる。るとより温度はできるた け均一に厈提失る小さいことが望ましい。この方法の久 点は定常状態に逞するまでの㭙間がや〉長く，かつ速結 部て均一度仙が起りやすいことである。

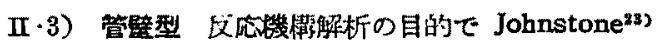
一派によって一連の研究に採用されたもので，反心管壁 を触媒面としたるのである。反応流体をゆっくり流すと 層流となり，したがって温度，澧度勾罪が知られ，触媒 表面の濃度が求められる。これに反し粒状触媒充填展て は橖膜抵抗を省略させるるには无分高速度で送万する必要 があるし，またその取扱いもわずらわしい。

管壁型反応器の反応速度の取扱いについては福井氏 ${ }^{32}$ の論文に詳しい。

\section{9. 不店逗度の近促表現}

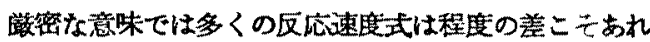
その本質として実駼的なるのであり，近似的なるのであ る。前節までは理論的なららつけに基ついてて説明を加え てきたか，本節では理諭的面を犠牲にした，単に垁験的 な解析法，閶便な取扱いすを一括して説明する。たたここ の简便法は通常その適用を測定筑围内に止をべきで，補 外には充分注意が必要なことはいらまでるない。

1）均一反底としての近倾 異相系反応ではとえ

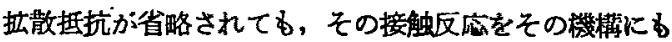
とつく速度式によって表すことは，式中の定数の決定と とすに多くは複雑であり, 充分な精度の実験か㴗求され

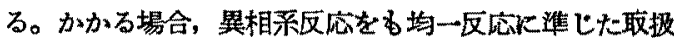
いによって実険的な速度式によって整理することがしば しばある。

流通法によれば，螌媒層 $d W$ で次の関係が成立する。

$$
F d x=r d W
$$

ここ $F$ : 供給速度， $x$ : 反応率，W:触媒犋量

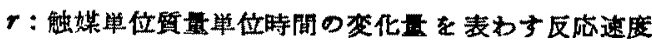
いま とを均一反沁に隼した取报いをなれば，前号に て説明したようにこれは活量あるいは，分王の函数であ 
る。全圧を 1気压とすると各成分の分殴はその $\mathrm{mol}$ 分 率 $N_{4}, N_{3}$ なと等しく，

$$
r=k f\left(N_{i}, N_{j}, \cdots\right)
$$

この函数形は反応次数によって洪り，したがって

$$
k \frac{d W}{F}=\frac{d x}{f\left(N_{i}, N_{j}, \cdots\right)}
$$

各成分の $\mathrm{mol}$ 分率は反度等 $x$ と量論的関係によって 相関され，右辺は $x$ のみの函数である。見掓け反応機

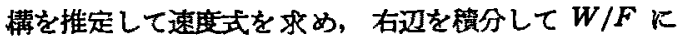
対坑して点緅すると，仮定が党当であれば，傾斜が速度 定数に等しい直線となる。あるい怯反应率を $W / F$ に対 空して点経し（21）式に示すように图上铔分して反応速 度を求め，仮定した反応機骤に基つく $\mathrm{mol}$ 分率の酷数 形に対広して示せば，適当な仮定であれば，傾斜が速店 定数を表わす㨁線となる。

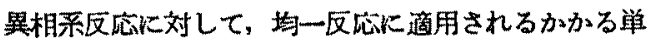
純な速度式を拯用することは諭議の余地があるが，かく して求められた嗃度式，速度定数性単一の化学過程に関 するすのではなく、吸着、表面反広，離脱などの実際の 反虑機㵒を組立てている諸過程を総合したものと同一の

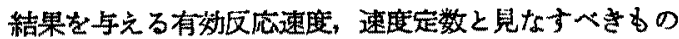
である。かかる近似的な取圾い、恃業反応にしばしば採 用されるるので，たとえば Smith24) らはメタンと硫暝 蒸気とのシリカゲル上の按触反応に，著者ら 253 はブチ ンジオール高生水添にからる取圾いをした。

2) 凝 1 次应 擬 1 次反応としての取扱いは, 広 く石油の熱分解、タール，木精油のクラッキング，木村の 加水分解のことき複雑な組成の原料の分解反底济適用さ れる。この場合原炓の反応率を基準にとるが，これを表 わすには原料の質量, mol あるいは原料の一定沸点範囲 の溜分の变化のよ5に実験的測定できる值に基つくか あるいは性成物のがス状分子の mol 数の增加に基つい、 ている。しかしいすれれ生成物の組成には考虑せず，別 個に反店率と生成物の組成变化の関低を图示などによっ て相関させる。

Hougen，Watson'つはこの取扱いの場合，速度定 数に次のような反応柬に庶ずる任意の実験的定数をつけ 加えるとさらによくまとまると説いてている。

$$
k=k_{0}(1-a x)
$$

ここに $k_{0}$ : 反広初期に括りる擬 1 次反応速度定数

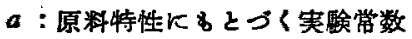

この式は反度率の小さい場合忙よいが，反応率が大き くなると、次のような变嵟が役立つといわれる。

$$
k=k_{0} /\left(1+a^{\prime} x\right)
$$

3）速度式の四示 英験的得られた結果に基つい。 て, 反応速度を反店条件に対応して図示し，装置設計に

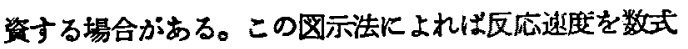
で表わすわずらはしさる，その機請に対する考察もさけ られるが，これには化範囲の㬰験が要求される。

Kirkbride $5^{26)}$ \& Thermofor catalytic cracking

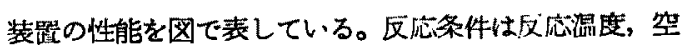
間速度，触婪一油比で，これらが反应生成物中のガス十 コータスの収率に対する影響をノモグラフ化して表わし ている。

反応速度缐图としては Wilke 27 の与えた 200atm に

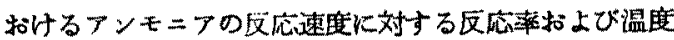
の関係を表わした図は著名であり，松山氏 反心塔設計に引用された。

この外速度線図には， $\mathrm{SO}_{2}$ の酸化に関する出合, ${ }^{39}$ 岡 本・進藤 ${ }^{30)}$ 氏らの報告などがある。

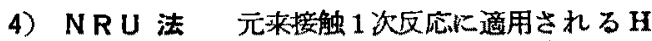
$\mathrm{RU}$ 法を均一反応江拉张したすので，近似的には婊面反 㐫律速的な接触反底にも適用できる。この詳細についてて

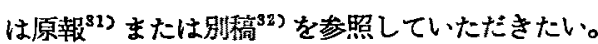

ただこれを取扱引場合の補外は $10 \%$ 程度の精度で測 定值の 2倍, および最小値の $1 / 2$ 程度にとどむべきであ る。

\section{結語}

反応装嘿設計に適用される速度諭を檥钼してきたが， いずれも合理的方法ではあるが，科学的には坆密なるの ではなく、ざら今後の研究発展に伴って改善発展さる べきのであろら。

記述す精涷宜しきを得ず，かつ充分䈍を尽せなかった 部分るかなり多かったことを掊訅びするととすに，説明 不充分の点は原論文に上って偖っていただきたい。

最後に Hougen ${ }^{17)}$ の言葉を引用して結びとする。 「今日の化学工菜といってり多くは街 (art)であり, 速度論の適用す単飞知的な推測にすきない場合が多い。 化学工学とは化学工莱の術と科学の領域との間覙を渡す 梠である。一般に科学の抽象的な表現を工業的生産の通 常の言葉火秋訳するのは化学技術者の任䅂である “Science of today is the engineering of tomorrow" $\rfloor$

\section{苦交献}

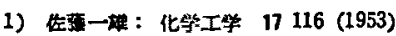

2) 大竹云鹤：近の化学工等 1950,1

3) 福井榙一：最近の化学工学 1954,129

4) Hougen, O. A. \& K. M. Watson : "Chem. Process Principles" part III (1947)

5) Hougen, O.A. \& K. M. Watson : Ind. Eng. Chem., 35529 (1943)

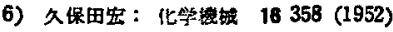

7) Hougen, O.A., 他: Trans. Am. Inst. Chem, Engrs., 391 (1943), 41445 (1945) 
8) Gamson. E.W. Chem. Eng. Pros., 6719 (1951)

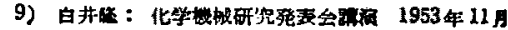

10) Yang, K. HI. \& O. A. Hougen: Chem. Eng: Prog., 46146 (1950)

11) Wilhelm, H. R.: Cham. Eng. Prog, 45208 (1949)

12) Hurt, D. M. : Ind. EnR. Cham, 35522 (1943)

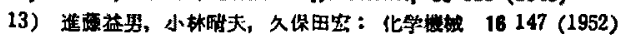

14) Thiele, E. W.: Ind. Eng. Chem, 31916 (1939)

15）新波忠夫：或近の化等工学 (1953)，165

16) Hougen, O.A. - Z. Elektrochemie 57479 (1953)

17) 1 (1951)

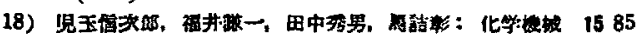
(1951)

19) Rescorla, A.R., J.A. Ottenweller \& R. S. Freeman : Analy. Chem., 20196 (1948)

20) Conn, M.E. \& G. C. Connelly: Ind. Eng. Chem., 391138 (1947)
21) Argo, W. B. \& J. M. Smith : Ind. Eng. Chem, 45 298 (1953)

22) 鬲詰新: 化学工学 17165,202 (1953)

23) Johnstone, H.F., 他: Chem. Eng. Prog.s 40125 (1952) Ind. Eng. Chem, 44 1564, 1570 (1952) 48703 (1954)

24) Nabor, G.W. \& J.M. Smith : Irad. Ens. Chem, 4t 1272 (1953)

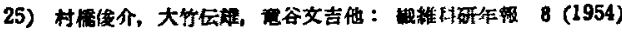

26) Schall, D.M., J.C. Dart \& C.G. Kirkbride : Chom. Eng. Prog., 45764 (1949)

27) Wilke, W.: Verfahrenstechnik, Nr.3 90 (1940)

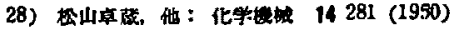

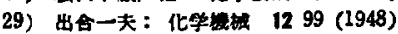

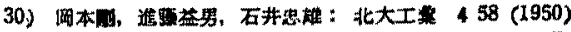

31) Caddell, J.R. \& D. M. Hurt: Chem. Eng. Proe., 47333 (1951)

32) 大竹伝知：化学之工来 6 386,436 (1953)

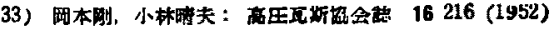

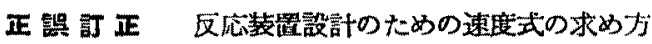

\begin{tabular}{|c|c|c|c|}
\hline & & I 均一相系及 & 19 巻, 㜢 1 号) 大竹㐾雉 \\
\hline 頁 & 住. 崫 & 运 & IE \\
\hline 29 & (16) 式 & $(R T)(a+b+c-r-s)$ & $(R T)(a+b+c-r-s)$ \\
\hline 29 & 第 1 表 & $1 / \mathrm{mol} \cdot \mathrm{sec}$ & $l / \mathrm{mol} \cdot \mathrm{sec}$ \\
\hline 29 & 第 1 垶 & $1^{2} / \mathrm{mol}^{2} \cdot \mathrm{sec}$ & $l^{2} / \mathrm{mol}^{2} \cdot \mathrm{sec}$ \\
\hline 31 & 例題 3 & $1.64 \times 10^{2}$ & $1.68 \times 10^{2}$ \\
\hline 33 & 例题 5 & $V$ av. $\ln \left(n_{A 0}-n_{A}\right)$ & Vav. $\ln \left(n_{A 0} / n_{A}\right)$ \\
\hline 34 & 台舆下你 & をこれと実測䚓を冰め， & を求めこれと夷測偲とを \\
\hline
\end{tabular}

\section{Chemical Engineering Fundamentals}

Chemical Engineering 誌は 1953年9月以降, Chem.

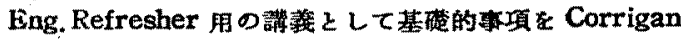
が担当して逢載している。いままでに発表された内容は

Thermodynamic Principles I - III (Sept.-Nov., 1953)

Compression \& Expansion I-III (Dec., 1953Feb., 1954)

Chemical Equilibrium I-IV (Mar.-June, 1954)

Reaction Kinetics (July, 1954- )

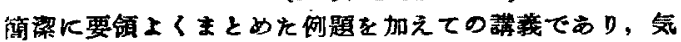

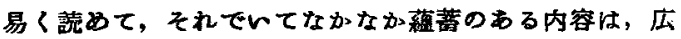

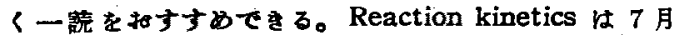
(1954) が Introduction であって, 工業反応速度䛿の 䁇義が述一られている。8〜10月加均一相系反応で，11

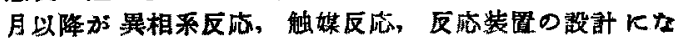

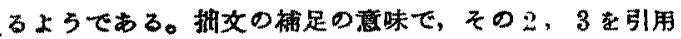
して説明うる。

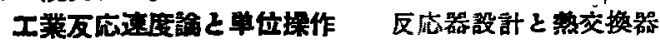
設計とを比較すると2つの点で逴いがある。その一つは

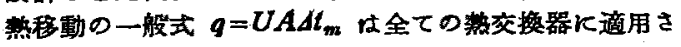
れるのК反し，反応速度を表わす速度式はその反応粮楼 に基ふレて単維なるのから椱雑なるのまでさまさまに变 化し；一律に取报らととはでない。他の一つめ相邀

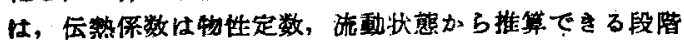
にあるが，反度速度定数は実駼的に求めねばならない。
化学反茫が充分研究されて，とれが操作条件から算出て

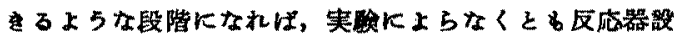
計は可能となるわけであるが，との段階は任ど蚍いのが 現状である。

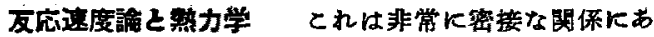
る。とるに反応系に対する組成，温度，圠力などの基本 的因子の影瑟を拷察するすのであるが，その相遈はとの

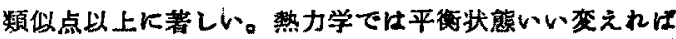

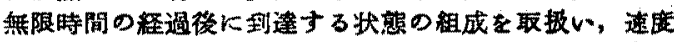

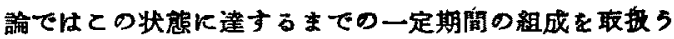
ので，整力学では時間を考えないが，速度論では時間が 主要な变数となっている。速度㬏では变化速度，反応

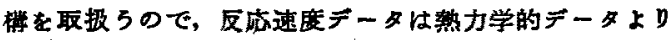
一般に取扱いが煩しいが，しかし反応速度データから上

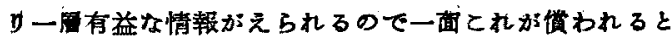

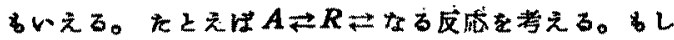
目的生成物が中間体 $R$ です，とれが释济的に充分回收 できるか各か知ろらとすれげ，熱力学定数を求め，これ によって平逼状態の湿合物中にはRが数\%であるてとが 知られたとすれば，熱力学的にはこの反成注有利でない

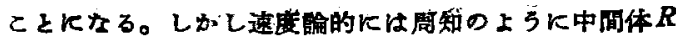
の淟度には反成時間に対して極大点が存在し，この点を

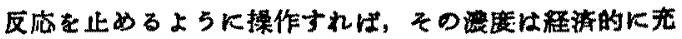
分引き合らことが考えられる。したがって整力学的判断

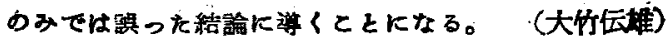

